\title{
Proteolytic release of membrane bound intercellular regulators
}

Peschon JJ, Slack JL, Reddy P, et al. An essential role for ectodomain shedding in mammalian development. Science 1998;282:1281-4.

\section{Abstract}

The ectodomains of numerous proteins are released from cells by proteolysis to yield soluble intercellular regulators. The responsible protease, tumor necrosis factor- $\alpha$ converting enzyme (TACE), has been identified only in the case when tumor necrosis factor- $\alpha$ (TNF $\alpha)$ is released. Analyses of cells lacking this metalloproteinase-disintegrin revealed an expanded role for TACE in the processing of other cell surface proteins, including a TNF receptor, the L-selectin adhesion molecule, and transforming growth factor- $\alpha$ (TGF $\alpha)$. The phenotype of mice lacking TACE suggests an essential role for soluble TGF $\alpha$ in normal development and emphasizes the importance of protein ectodomain shedding in vivo.

\section{Comment}

The article by Peschon et al provides new insights into the biological importance of enzymes which cleave off membrane bound peptide intercellular regulators. Many functionally diverse proteins, including cytokines, growth factors and their receptors, are initially synthesised as membrane anchored molecules that are subsequently released from the cell by proteolysis. The enzymes responsible for this cleavage are largely unknown except that for one protein, tumour necrosis factor (TNF) $\alpha$, which was studied by the investigators in detail. They showed that this enzyme, TNF- $\alpha$ converting enzyme (TACE), is responsible for the proteolytic cleavage of $\mathrm{TNF}-\alpha$ and also of other intercellular regulators such as the TNF receptor, the L-selectin adhesion molecule and transforming growth factor (TGF) $\alpha$.

The investigators created mutations targeted to TACE (tace ${ }^{-\mathrm{Zn} / \mathrm{Zn}}$ mice). The zinc binding domains of this enzyme were thereby deleted, causing inactivation of the metalloproteinase activity. TNF- $\alpha$ release was therefore efficiently blocked. Crossbreeding of mice heterozygous for this mutation (tace ${ }^{-\mathrm{Zn} / \mathrm{Zn}}$ mice) surprisingly resulted in a notable under-representation of tace ${ }^{-\mathrm{Zn} / \mathrm{Zn}}$ mice, probably as a result of intrauterine death. The studies showed that most tace $^{-\mathrm{Zn} /-\mathrm{Zn}}$ mice died between day 17.5 and the first day after birth. As mice lacking TNF or its receptor are overtly normal, it was suspected that TACE has activities in addition to release of TNF. Surprisingly, surviving newborn tace ${ }^{-\mathrm{Zn} /-\mathrm{Zn}}$ mice had phenotypic features similar to those of mice lacking TGF- $\alpha^{12}$ such as open eye lids (eye lids do normally not open until postnatal day 14), perturbed hair coats and curly vibrissae.

In vitro studies on embryonic fibroblasts confirmed that TACE cleaves both TNF- $\alpha$ and TGF- $\alpha$. Cells obtained from tace ${ }^{-\mathrm{Zn} / \mathrm{Zn}}$ mice released 20 times less soluble TGF- $\alpha$ compared with those obtained from wild type mice. These studies also provided new insights into the role of TGF- $\alpha$ after it has been released from the cell surface. It became evident that released TGF- $\alpha$, but not membrane bound TGF- $\alpha$, is essential for normal hair follicle and eyelid development. Additional studies showed that TACE has further activities such as mediating release of L-selectin and the p75 receptor of TNF (p75 TNFR). Peschon et al also showed that TACE is noticeably more efficient at cleaving TNF- $\alpha$ than TGF- $\alpha$ or L-selectin.

In summary, these studies suggest a critical role for TACE in the processing of multiple proteins including TNF- $\alpha$, TGF- $\alpha$ and L-selectin. Targeting this enzyme with specific inhibitors may facilitate the development of new therapeutic approaches to many diseases such as inflammatory bowel disease and rheumatoid arthritis where blockade of TNF- $\alpha$ has been proved to be of clinical benefit. ${ }^{3-5}$ For the treatment of inflammatory bowel disease it will be essential to block predominantly TNF- $\alpha$ and not TGF- $\alpha$, which is a mediator of mucosal protection and repair as shown in animal studies of experimental colitis. ${ }^{67}$ These new discoveries will hopefully provide new strategies for the treatment of inflammatory diseases.

V E EYSSELEIN Harbor-UCLA Medical Center, Division of Gastroenterology, 1000 West Carson Street, N-21, Torrance, CA 90509, USA

1 Luetteke NC, Qiu TH, Peiffer RL, et al. TGF $\alpha$ deficiency results in hair follicle and eye abnormalities in targeted and waved-1 mice. Cell 1993;73:263-78.

2 Mann GB, Fowler KJ, Gabriel A, et al. Mice with a null mutation of the TGF- $\alpha$ gene have abnormal skin architecture, wavy hair, and curly whiskers and often develop corneal inflammation. Cell 1993;73:249-61.

3 Targan SR, Hanauer SB, van Deventer SJ, et al. A short-term study of chimeric monoclonal antibody cA2 to tumor necrosis factor alpha for Crohn's disease. Crohn's Disease cA2 Study Group. N Engl F Med 1997;337:1029-

4 van Dullemen HM, van Deventer SJ, Hommes DW, et al. Treatment of Crohn's disease with anti-tumor necrosis factor chimeric monoclonal antibody (cA2). Gastroenterology 1995;109:129-35.

5 Elliott MJ, Maini RN, Feldmann M, et al. Randomised double-blind comparison of chimeric monoclonal antibody to tumour necrosis factor alpha (cA2) versus placebo in rheumatoid arthritis. Lancet 1994;344:110510 .

6 Egger B, Procaccino F, Lakshmanan J, et al. Mice lacking transforming growth factor-alpha have an increased susceptibility to dextran sulfate induced colitis. Gastroenterology 1997;113:825-32.

7 Egger B, Carey HV, Procaccino F, et al. Reduced susceptibility of mice overexpressing transforming growth factor $\alpha$ to dextran sodium sulphate induced colitis. Gut 1998;43:64-70. 